\title{
Hubungan Hukum Para Pihak \\ Dalam Layanan Urun Dana Melalui Penawaran Saham Berbasis Teknologi Informasi
}

\author{
Ratna Hartanto \\ Fakultas Hukum Universitas Islam Indonesia \\ Jln. Tamansiswa No. 158 Yogyakarta \\ 104100101@uii.ac.id
}

Received: 21 Desember 2019; Accepted: 24 Maret 2020; Published: 29 Juni 2020

DOI: 10.20885/iustum.vol27.iss1.art8

\begin{abstract}
The development of information technology has provided many facilities for business entities to obtain funding. One way to obtain funding without going through an initial public offering process is through equity crowdfunding. Equity crowdfunding is a platform system developed and managed by a host company. The platform can be used by publishing companies to offer securities in the form of shares to buyers or investors. Equity crowdfunding investors need legal certainty and legal protection for their investments. On the other hand, equity issuers and platform operators also need to get legal certainty from the Financial Services Authority. The Financial Services Authority has issued Financial Services Authority Regulation (POJK) Number 37/POJK.04/2018 regarding Funding Services through Information Technology Based Shares (Equity Crowdfunding). The problem examined in this paper is how the construction of legal relations and legal protection for the parties in equity crowdfunding in Indonesia. This study uses a normative method by reviewing the laws and regulations related to the legal issues studied. The results of the study concluded that the parties in holding equity crowdfunding, namely share issuers, organizers, and investors, all three has a triangular relationship that is born based on agreements or laws and regulations. Even though the OJK has issued regulations relating to equity crowdfunding, the current regulations do not guarantee full legal protection especially for investors.
\end{abstract}

Keywords: Equity crowdfunding; legal relationships; the parties

Abstrak

Perkembangan teknologi informasi telah memberikan banyak kemudahan bagi badan usaha guna mendapatkan pendanaan. Salah satu cara perolehan pendanaan tanpa melalui proses penawaran umum (initial public offering) yaitu melalui equity crowdfunding. Equity crowdfunding merupakan sistem platform yang dikembangkan dan dikelola oleh perusahaan penyelenggara. Platform tersebut dapat digunakan oleh perusahaan penerbit untuk menawarkan efek berupa saham kepada pembeli atau investor. Investor equity crowdfunding perlu mendapatkan kepastian hukum serta perlindungan hukum atas investasi yang dilakukannya. Di sisi lain, penerbit equity serta penyelenggara platform juga perlu mendapatkan kepastian hukum dari Otoritas Jasa Keuangan. Otoritas Jasa Keuangan telah menerbitkan Peraturan Otoritas Jasa Keuangan (POJK) Nomor 37/POJK.04/2018 tentang Layanan Urun Dana Melalui Penawaran Saham Berbasis Teknologi Informasi (Equity Crowdfunding). Permasalahan yang dikaji dalam penulisan ini adalah bagaimana konstruksi hubungan hukum serta perlindungan hukum bagi para pihak dalam equity crowdfunding di Indonesia. Penelitian ini menggunakan metode normatif dengan mengkaji peraturan perundang-undangan terkait permasalahan hukum yang diteliti. Hasil penelitian menyimpulkan bahwa para pihak dalam penyelenggaraan equity crowdfunding, yaitu penerbit saham, penyelenggara, dan pemodal, ketiganya memiliki triangular relationship yang lahir berdasarkan perjanjian maupun peraturan perundang-undangan. Meskipun OJK telah menerbitkan peraturan terkait equity crowdfunding, pengaturan yang ada saat ini belum memberikan jaminan perlindungan hukum sepenuhnya khususnya bagi pemodal.

Kata-kata Kunci : Equity crowdfunding; hubungan hukum; para pihak 


\section{Pendahuluan}

Perkembangan teknologi khususnya teknologi informasi telah membawa dampak yang signifikan terhadap industri jasa keuangan di seluruh dunia. Masyarakat saat ini dapat dengan mudah memperoleh akses produk keuangan dengan adanya teknologi informasi internet melalui smartphone yang dimiliki. Berbagai produk dan layanan keuangan dapat dinikmati oleh masyarakat secara luas dengan adanya financial technology (fintech) atau teknologi finansial seperti peer to peer lending. Begitu pula dengan project owner ataupun pengusaha yang memiliki ide dan kreatifitas namun memiliki keterbatasan pendanaan dapat memperoleh pendanaan atas project-nya tanpa mengajukan pinjaman ke bank melainkan mengupayakan pendanaan dari masyarakat secara luas dengan memanfaatkan kecanggihan teknologi finansial yang disebut dengan equity crowdfunding. ${ }^{1}$

Berdasarkan Undang-Undang No. 8 Tahun 1995 tentang Pasar Modal, bagi suatu perseroan terbatas yang menginginkan menjual saham ke masyarakat luas maka terhadapnya berlaku segala ketentuan penawaran umum (initial public offering) sebagaimana diatur dalam Undang-Undang No. 8 Tahun 1995 tentang Pasar Modal..$^{2}$ Perseroan terbatas tersebut tentunya telah melakukan rapat umum pemegang saham guna menyepakati perubahan status perseroan dari tertutup menjadi terbuka yang selanjutnya diikuti dengan perubahan anggaran dasar perseroan baik terkait perubahan jumlah modal minimal, ${ }^{3}$ maupun perubahan jenis perseroan.

Setelah perubahan anggaran dasar mendapat persertujuan Menteri Hukum dan Hak Asasi Manusia, ${ }^{4}$ maka perseroan terbatas harus mengajukan

\footnotetext{
${ }^{1}$ Lady Aprilia dan Sigit S. Wibowo, "The Impact of Social Capital On Crowdfunding Performance" The South East Asean Journal of Management, Vol. 11 No. 1. 2017

${ }^{2}$ Lihat Pasal 1 angka 15 Undang-Undang No. 8 Tahun 1998 tentang Pasar Modal yang menyatakan bahwa Penawaran Umum adalah kegiatan penawaran Efek yang dilakukan oleh Emiten untuk menjual Efek kepada masyarakat berdasarkan tata cara yang diatur dalam undang-undang ini dan peraturan pelaksanaannya.

3 Lihat Pasal 1 angka 22 Undang-Undang No. 8 Tahun 1998 tentang Pasar Modal yang menyatakan bahwa Perusahaan Publik adalah Perseroan yang sahamnya telah dimiliki sekurang-kurangnya oleh 300 (tiga ratus) pemegang saham dan memiliki modal disetor sekurang-kurangnya Rp. 3.000.000.000,00 (tiga miliar rupiah) atau suatu jumlah pemegang saham dan modal disetor yang ditetapkan dengan Peraturan Pemerintah.

4 Pasal 15 ayat (1) Undang-Undang No. 40 Tahun 2007 menyatakan bahwa Anggaran Dasar perseroan memuat sekurang-kurangnya antara lain besarnya jumlah modal dasar, modal ditempatkan, dan modal disetor . Selanjutnya Pasal 21 Undang-Undang No. 40 Tahun 2007 tentang Perseroan Terbatas menyatakan bahwa perubahan anggaran dasar yang harus mendapat persetujuan Menteri yakni perubahan atas nama perseroan dan/atau tempat kedudukan perseroan, maksud dan tujuan serta kegiatan usaha perseroan, jangka waktu berdirinya perseroan, besarnya modal dasar, pengurangan modal ditempatkan dan disetor, dan/atau status perseroan yang tertutup menjadi perseroan terbuka atau sebaliknya
} 
permohonan pendaftaran emisi saham kepada Otoritas Jasa Keuangan guna memperoleh 'pernyataan efektif' 5 dari Otoritas Jasa Keuangan agar perseroan terbatas tersebut dapat melakukan penawaran umum. Perseroan terbatas juga perlu bekerja sama dengan Perusahaan Efek selaku penjamin emisi (underwriter), lembaga penunjang, dan beberapa profesi penunjang pasar modal diantaranya konsultan hukum pasar modal dan akuntan publik. ${ }^{6}$

Investor atau pemodal, masyarakat maupun badan hukum yang hendak membeli saham di pasar perdana harus mendapatkan lembaran formulir pemesanan pembelian penawaran umum yang disebut Formulir Pemesanan Pembelian Saham (FPPS). Formulir ini merupakan bagian tak terpisahkan dengan prospektus ringkas. Selain itu masyarakat atau investor dapat menghubungi agen penjualan yang ditunjuk oleh Penjamin Pelaksana Emisi initial public offering dan meminta formulir tersebut. ${ }^{7}$

Perkembangan finansial teknologi saat ini telah memberikan opsi penjualan saham oleh perseroan terbatas kepada masyarakat secara luas guna mendapatkan dana bagi perusahaan tanpa melalui penawaran umum saham (initial public offering) sebagaimana diatur dalam Undang-Undang No. 8 Tahun 1995 tentang Pasar Modal. ${ }^{8}$ Teknologi informasi menciptakan inklusifitas layanan keuangan sehingga akses atas produk maupun layanan keuangan menjadi sangat beragam. Salah satu inovasi teknologi dalam industri jasa keuangan, yang dapat digunakan masyarakat adalah Layanan Urun Dana melalui penawaran saham berbasis Teknologi Informasi, atau yang lebih dikenal dengan Layanan Urun Dana (Equity Crowdfunding).

\footnotetext{
5 Penjelasan Pasal 5 huruf d Undang-Undang No. 8 Tahun 1995 tentang Pasar Modal menyatakan bahwa Pernyataan efektif dalam hal ini menunjukkan lengkap atau dipenuhinya seluruh prosedur dan persyaratan atas Pernyataan Pendaftaran yang diwajibkan dalam undang-undang ini dan atau peraturan pelaksanaannya. Pernyataan efektif tersebut bukan merupakan izin untuk melakukan Penawaran Umum dan juga bukan berarti bahwa Bapepam menyatakan informasi yang diungkapkan Emiten atau Perusahaan Publik tersebut adalah benar atau cukup.

${ }^{6}$ Nindyo Paramono, Hukum PT Go Public dan Pasar Modal, Andi, Yogyakarta, 2013, hlm. 339.

${ }^{7}$ Tjiptono Darmadji dan Hendy M. Fakhruddin, Pasar Modal Indonesia Edisi 3, Salemba Empat, Jakarta, 2011, hlm. 70.

${ }^{8}$ Pasal 5 ayat (1) POJK No. 37 /POJK.04/2018 tentang Layanan Urun Dana Melalui Penawaran Saham Berbasis Teknologi Informasi (Equity Crowdfunding) menyatakan bahwa Penawaran saham oleh setiap Penerbit melalui Layanan Urun Dana bukan merupakan penawaran umum sebagaimana dimaksud dalam Undang-Undang Nomor 8 Tahun 1995 tentang Pasar Modal jika penawaran saham dilakukan melalui Penyelenggara yang telah memperoleh izin dari Otoritas Jasa Keuangan; penawaran saham dilakukan dalam jangka waktu paling lama 12 (dua belas) bulan; dan otal dana yang dihimpun melalui penawaran saham paling banyak Rp10.000.000.000,00 (sepuluh miliar rupiah).
} 
Kata crowdfunding bermakna the practice of getting a large number of people to each small amounts of money in order to provide the finance for a business project, typically using the internet. ${ }^{9}$ Crowdfunding berdasarkan definisi tersebut merupakan praktik yang melibatkan banyak orang dalam penggalangan dana guna memenuhi kebutuhan finansial bisnis atau kegiatan tertentu dengan menggunakan teknologi internet. Dana yang terkumpul atas penyelenggaraan crowdfunding tersebut dapat digunakan untuk berbagai keperluan seperti penyelesaian proyek tertentu, donasi kegiatan kemanusiaan, dan lainnya. Crowdfunding dalam hal ini terdapat beberapa macam diantaranya donation based crowdfunding, reward based crowdfunding, lending based crowdfunding, equity based crowdfunding. ${ }^{10}$

Equity Crowdfunding merupakan penyelenggaraan layanan penawaran saham yang dilakukan oleh penerbit untuk menjual saham secara langsung kepada pemodal melalui jaringan sistem elektronik yang bersifat terbuka. ${ }^{11}$ Berdasarkan definisi tersebut, para pihak yang terlibat dalam equity crowdfunding yaitu penerbit, platform penyelenggara yang memiliki jaringan sistem elektronik yang bersifat terbuka, serta pemodal. Melalui equity crowdfunding, perseroan terbatas selaku penerbit saham dapat menjual saham yang dimilikinya ke masyarakat sehingga memperoleh tambahan dana bagi operasional perusahaan.

Pemodal pada sisi yang lain juga akan mendapatkan saham perseroan terbatas tertentu atas dana yang telah disetorkan kepada perusahaan penyelenggara. Praktik equity crowdfunding yang mempermudah perusahaan dalam perolehan pendanaan merupakan hal yang selaras dengan inklusi keuangan yang ditargetkan oleh pemerintah. Inklusi keuangan ini sendiri telah diatur dalam Peraturan Presiden No. 82 Tahun 2016 tentang Strategi Nasional Keuangan Inklusif (SNKI) bahwa sistem keuangan inklusif diwujudkan melalui akses masyarakat terhadap layanan keuangan sehingga dapat meningkatkan kemampuan ekonomi dan membuka jalan untuk keluar dari kemiskinan serta mengurangi kesenjangan ekonomi.

\footnotetext{
${ }^{9}$ https://dictionary.cambridge.org/dictionary/english/crowdfunding diakses pada tanggal 6 September 2019 pukul 15.43 WIB.

${ }^{10}$ Gustaf Josua at.al, "Tinjauan Yuridis Terhadap Penerapan Prinsip Keterbukaan Dan Mitigasi Resiko Pada Equity Crowdfunding Di Indonesia” Jurnal Hukum Fakultas Hukum Universitas Brawijaya, 2019

11 Pasal 1 angka 1 POJK No. 37 /POJK.04/2018 tentang Layanan Urun Dana Melalui Penawaran Saham Berbasis Teknologi Informasi (Equity Crowdfunding)
} 
Equity Crowdfunding untuk pertama kali diterapkan di Inggris dengan platform pertama penyelenggara yakni Crowdcube. Sejak saat itu, Equity Crowdfunding secara cepat berkembang di berbagai negara. Pada 2013, Bank Dunia menyatakan terdapat 672 penyelenggara Equity Crowdfunding dengan estimasi nilai pasar di seluruh dunia berkisar US $\$ 96.000 .0000 .000 .{ }^{12}$

Pasca ditetapkannya POJK No. 37 /POJK.04/2018 tentang Layanan Urun Dana Melalui Penawaran Saham Berbasis Teknologi Informasi (Equity Crowdfunding), terdapat beberapa perusahaan yang mengajukan permohonan sebagai penerbit. Bursa Efek Indonesia (BEI) mengungkapkan sudah ada sembilan platform yang mengajukan izin sebagai penyelenggara fasilitas urun danaatau Equity Crowd Funding (ECF) ke Otoritas Jasa Keuangan (OJK). ${ }^{13}$

Kegiatan Layanan Urun Dana (equity crowdfunding) sebagaimana dimaksud dalam Peraturan Otoritas Jasa Keuangan ini merupakan kegiatan jasa keuangan di sektor Pasar Modal. ${ }^{14}$ Mengingat potensi risiko yang ada bagi para pihak dalam equity crowdfunding, pengaturan dan pengawasan eksistensi equity crowdfunding perlu dilakukan oleh Otoritas Jasa Keuangan. Mengingat equity crowdfunding berbeda dengan penawaran umum saham sebagaimana diatur dalam Undang-Undang No. 8 Tahun 1995 tentang Pasar Modal, penentuan konstruksi hubungan hukum antara para pihak dalam equity crowdfunding merupakan hal yang esensi. Hal ini diperlukan guna mewujudkan kepastian dan perlindungan hukum bagi para pihak, baik penerbit, platform penyelenggara, maupun pemodal, dalam berinvestasi melalui equity crowdfunding.

\section{Rumusan Masalah}

Berdasarkan uraian di atas, penelitian ini fokus pada rumusan masalah yaitu: pertama, bagaimana konstruksi hubungan hukum para pihak dalam Layanan Urun Dana melalui Penawaran Saham Berbasis Teknologi Informasi

\footnotetext{
${ }^{12}$ Lynda Y. de la Vina dan Stephanie Lee Black, "US Equity Crowdfunding: A Review of Current Legislation and A Conceptual Model of The Implications For Equity Funding", The Journal of Entrepreneurship, Sage Publications, 2017

${ }^{13}$ https://market.bisnis.com/read/20190923/7/1151262/bei-9-platform-sudah-mengajukan-diri-jadiequity-crowd-funding diakses pada tanggal 25 September 2019 pukul 16.17 WIB

14 Pasal 4 ayat (1) POJK No. 37 /POJK.04/2018 tentang Layanan Urun Dana Melalui Penawaran Saham Berbasis Teknologi Informasi (Equity Crowdfunding)
} 
(equity crowdfunding) di Indonesia? Kedua, bagaimana perlindungan hukum bagi para pihak dalam Layanan Urun Dana melalui Penawaran Saham Berbasis Teknologi Informasi (equity crowdfunding) di Indonesia?

\section{Tujuan Penelitian}

Penelitian ini bertujuan untuk mengetahui hubungan hukum dan perlindungan hukum bagi para pihak dalam Layanan Urun Dana melalui Penawaran Saham Berbasis Teknologi Informasi (equity crowdfunding) di Indonesia.

\section{Metode Penelitian}

Penelitian ini adalah jenis penelitian hukum normatif yang mendasarkan analisanya pada peraturan perundang-undangan yang terkait dengan permasalahan penelitian yang dikaji. Pendekatan yang digunakan dalam penelitian ini adalah pendekatan perundang-undangan dan pendekatan konseptual, yaitu meninjau semua permasalahan yang diteliti berlandaskan kajiannya kepada konsep-konsep hukum dalam teori atau doktrin. Data yang digunakan dalam penelitian ini adalah data sekunder yang terdiri dari bahan hukum primer yaitu bahan hukum yang berasal dari dokumen-dokumen resmi seperti Kitab Undang-Undang Hukum Perdata, Undang-Undang No. 8 Tahun 1995 tentang Pasar Modal, Undang-Undang No. 40 Tahun 2007 tentang Perseroan Terbatas, dan POJK No. 37/POJK.04/2018 tentang Layanan Urun Dana Melalui Penawaran Saham Berbasis Teknologi Informasi (Equity Crowdfunding) serta bahan hukum sekunder yang terdiri dari buku-buku yang relevan dengan penelitian, jurnal, media informasi melalui internet, dan sumber lainnya yang berhubungan dan berkaitan dengan permasalahan yang diteliti.

Metode pengumpulan data dilakukan dengan teknik studi kepustakaan untuk mengumpulkan bahan-bahan hukum primer dan sekunder, kemudian akan disajikan dengan cara mendiskripsikan data dan bahan hukum tersebut. Pengumpulan data juga akan dilengkapi dengan melakukan studi dokumen terhadap perjanjian dan dokumen-dokumen lain yang terkait dengan penelitian ini. Melihat pada sifat penelitian yang menggunakan pendekatan doktrinal maka sifat analisisnya adalah deskriptif dengan model narasi isi (content analysis), yang 
akan menguraikan dan mengorganisasikan konsep dan pengaturan tentang hukum perjanjian yang berlaku di Indonesia sehingga akan tampak jelas jawaban dari permasalahan yang dikaji sebagai kesimpulan dalam penelitian ini.

\section{Hasil Penelitian dan Pembahasan}

\section{Hubungan Hukum Para Pihak dalam Layanan Urun Dana Melalui Penawaran Saham Berbasis Teknologi Informasi (Equity Crowdfunding) di Indonesia}

Hubungan hukum antara para pihak dalam equity crowdfunding merupakan hubungan hukum antara tiga pihak (triangular relationship) yakni penerbit, penyelenggara, dan pemodal. Adapun uraian hubungan hukum tersebut dapat dideskripsikan sebagai berikut.

\section{Penerbit}

Penerbit adalah badan hukum Indonesia berbentuk perseroan terbatas yang menawarkan saham melalui Penyelenggara. ${ }^{15}$ Penerbit harus perseroan terbatas mengingat badan hukum di Indonesia yang dapat menerbitkan saham adalah perseroan terbatas. Penerbit bukan merupakan perusahaan publik sebagaimana dimaksud dalam Undang-Undang Nomor 8 Tahun 1995 tentang Pasar Modal jika jumlah pemegang saham Penerbit tidak lebih dari 300 pihak dan jumlah modal disetor Penerbit tidak lebih dari Rp. 30.000.000.000,00.16

\section{Penyelenggara}

Penyelenggara equity crowdfunding adalah badan hukum Indonesia berbentuk perseroan terbatas atau koperasi. ${ }^{17}$ Perseroan terbatas tersebut dapat berupa Perusahaan Efek yang telah memperoleh persetujuan dari Otoritas Jasa Keuangan untuk melakukan kegiatan lain sebagai Penyelenggara. Sedangkan penyelenggara yang berbadan hukum koperasi hanya terbatas pada jenis koperasi jasa. ${ }^{18}$

\footnotetext{
15 Pasal 1 angka 6 POJK No. 37 /POJK.04/2018 tentang Layanan Urun Dana Melalui Penawaran Saham Berbasis Teknologi Informasi (Equity Crowdfunding)

16 Pasal 6 POJK No. 37 /POJK.04/2018 tentang Layanan Urun Dana Melalui Penawaran Saham Berbasis Teknologi Informasi (Equity Crowdfunding)

17 Pasal 10 POJK No. 37 /POJK.04/2018 tentang Layanan Urun Dana Melalui Penawaran Saham Berbasis Teknologi Informasi (Equity Crowdfunding)

18 Pasal 11 POJK No. 37 /POJK.04/2018 tentang Layanan Urun Dana Melalui Penawaran Saham Berbasis Teknologi Informasi (Equity Crowdfunding)
} 
Penyelenggara yang berbentuk perseroan terbatas maupun koperasi harus memiliki modal disetor paling sedikit Rp. 2.500.000.000,00 pada saat mengajukan permohonan perizinan. ${ }^{19}$ Penyelenggara yang akan melakukan Layanan Urun Dana (equity crowdfunding) wajib memiliki izin usaha dari Otoritas Jasa Keuangan. ${ }^{20}$

\section{Pemodal}

Pemodal adalah pihak yang melakukan pembelian saham Penerbit melalui Penyelenggara. ${ }^{21}$ Pemodal dapat berupa perorangan maupun badan hukum. Khusus untuk pemodal perorangan yang belum mempunyai pengalaman berinvestasi di Pasar Modal yang dibuktikan dengan kepemilikan rekening Efek paling sedikit 2 tahun sebelum penawaran saham, maka harus memenuhi kualifikasi sebagaimana diatur dalam Pasal 42 POJK No. 37 /POJK.04/2018 tentang Layanan Urun Dana Melalui Penawaran Saham Berbasis Teknologi Informasi (Equity Crowdfunding) yaitu:

a. setiap Pemodal dengan penghasilan sampai dengan Rp. 500.000.000,00 (lima ratus juta rupiah) per tahun, dapat membeli saham melalui Layanan Urun Dana paling banyak sebesar 5\% (lima persen) dari penghasilan per tahun; dan

b. setiap Pemodal dengan penghasilan lebih dari Rp. 500.000.000,00 (lima ratus juta rupiah) per tahun, dapat membeli saham melalui Layanan Urun Dana paling banyak sebesar 10\% (sepuluh persen) dari penghasilan per tahun.

Batasan sebagaimana disebutkan di atas tidak berlaku bagi badan hukum maupun perorangan yang telah memiliki pengalaman berinvestasi di pasar modal.

POJK No. 37/POJK.04/2018 tentang Layanan Urun Dana Melalui Penawaran Saham Berbasis Teknologi Informasi (Equity Crowdfunding) tidak memberikan batasan atas pemilikan saham asing pada perusahaan penerbit equity crowdfunding. Hal ini berarti warna negara asing maupun badan hukum asing memiliki peluang untuk menjadi pemegang saham perusahaan penerbit. Pengaturan peluang masuknya asing sebagai pemegang saham perusahaan

\footnotetext{
19 Pasal 12 POJK No. 37 /POJK.04/2018 tentang Layanan Urun Dana Melalui Penawaran Saham Berbasis Teknologi Informasi (Equity Crowdfunding)

20 Pasal 7 POJK No. 37 /POJK.04/2018 tentang Layanan Urun Dana Melalui Penawaran Saham Berbasis Teknologi Informasi (Equity Crowdfunding)

21 Pasal 1 angka 7 POJK No. 37 /POJK.04/2018 tentang Layanan Urun Dana Melalui Penawaran Saham Berbasis Teknologi Informasi (Equity Crowdfunding)
} 
penerbit ini berbeda jika dibandingkan dengan POJK No. 77/POJK.01/2016 tentang Layanan Pinjam Meminjam Berbasis Teknologi Informasi, karena Penerima pinjaman dalam sistem peer to peer lending harus berasal dan berdomisili di wilayah hukum Negara Kesatuan Republik Indonesia. Penerima pinjaman dapat berupa orang perseorangan Warga Negara Indonesia atau badan hukum Indonesia. ${ }^{22}$ Ketentuan mengenai peer to peer lending tersebut jelas membatasi penerima pinjaman berdasarkan kewarganegaraan yang dimiliki.

Otoritas Jasa Keuangan kedepan perlu mengatur mengenai batasan kepemilikan saham asing melalui equity crowdfunding mengingat jika dilihat dari batasan modal yang dipersyaratkan OJK atas penerbit, maka penerbit adalah perusahaan pemula yang perlu dibantu dalam perolehan dana operasional perusahaan. Hal inipun selaras jika ditinjau pada bagian kosideran POJK tentang equity crowdfunding yaitu mendukung pelaku usaha pemula (start-up company) untuk berkontribusi terhadap perekonomian nasional melalui penyediaan alternatif sumber pendanaan berbasis teknologi informasi.

Meskipun POJK tentang Equity Crowdfunding tidak mengatur mengenai batasan pemilikan saham oleh asing, para pihak perlu memperhatikan batasan pemilikan saham asing yang berlaku pada sektor-sektor usaha tertentu. Adapun berdasarkan Peraturan Presiden No. 44 Tahun 2016 tentang Daftar Negatif Investasi, batasan kepemilikan asing dalam perusahaan penyelenggara transaksi perdagangan melalui sistem elektronik hanya diperbolehkan maksimal $49 \%$ bila investasi di bawah Rp. 100.000.000.000,00, sementara untuk investasi di atas Rp. 100.000.000.000,00, tidak ada batasan kepemilikan modal. ${ }^{23}$

\section{Hubungan antara Para Pihak dalam Equity Crowdfunding dapat Dijabarkan Satu Persatu Sebagai Berikut.}

\section{Hubungan Hukum antara Penerbit dan Penyelenggara}

Penerbit dan penyelenggara equity crowdfunding memiliki hubungan hukum yang lahir dari perjanjian penyelenggaraan layanan urun dana (equity

\footnotetext{
Informasi

22 Pasal 15 POJK No. 77/POJK.01/2016 tentang Layanan Pinjam Meminjam Berbasis Teknologi

${ }^{23}$ https://teknologi.bisnis.com/read/20190808/266/1134219/investor-asing-di-startup-indonesia-masihtuai-kontroversi diakses pada tanggal 8 September 2019 pukul 15.49 WIB
} 
crowdfunding). Perjanjian penyelenggaraan Layanan Urun Dana antara Penyelenggara dan Penerbit dituangkan dalam akta. Akta tersebut dapat berupa akta notaris. Akta tersebut dapatberbentuk Dokumen Elektronik. Perjanjian penyelenggaraan equity crowdfunding tersebut harus paling sedikit memuat nomor perjanjian, tanggal perjanjian, identitas para pihak, ketentuan mengenai hak dan kewajiban para pihak, jangka waktu atau pengakhiran perjanjian, jumlah dana yang akan dihimpun dan saham yang akan ditawarkan, jumlah minimum dana, jika menetapkan jumlah minimum dana yang harus diperoleh, besarnya komisi dan biaya, ketentuan mengenai denda, jika terdapat ketentuan mengenai denda, mekanisme penyelesaian sengketa, dan mekanisme penyelesaian dalam hal penyelenggara tidak dapat melanjutkan kegiatan operasionalnya. ${ }^{24}$

Penerbit hanya dapat menawarkan saham melalui satu penyelenggara dalam waktu yang bersamaan. Batas maksimum penghimpunan dana melalui Layanan Urun Dana oleh setiap Penerbit dalam jangka waktu 12 bulan paling banyak sebesar Rp. 10.000.000.000,00.25

Perjanjian antara penerbit dan penyelenggara merupakan pemberian kuasa dari penerbit kepada penyelenggara untuk menawarkan saham yang dimiliki penerbit kepada masyarakat luas melalui sistem informasi yang dimiliki oleh penyelenggara. Kedudukan penerbit dalam konsep equity crowdfunding tidak dibenarkan menawarkan sahamnya kepada masyarakat tanpa melalui penyelenggara. Setelah terjadi kesepakatan beli dari pemodal, maka uang yang diterima penyelenggara akan diteruskan kepada penerbit dan selanjutnya saham akan didistribusikan oleh penyelenggara kepada pemodal.

\section{Hubungan Hukum antara Penyelenggara dan Pemodal}

Penyelenggara dan pemodal dalam equity crowdfunding memiliki hubungan hukum yang lahir dari perjanjian penyelenggaraan Layanan Urun Dana. Perjanjian penyelenggaraan Layanan Urun Dana antara Penyelenggara dan Pemodal dituangkan dalam bentuk perjanjian baku. Mengikatnya perjanjian tersebut terjadi pada saat Pemodal menyatakan persetujuan secara elektronik atas

\footnotetext{
${ }_{24}$ Pasal 44 POJK No. 37 /POJK.04/2018 tentang Layanan Urun Dana Melalui Penawaran Saham Berbasis Teknologi Informasi (Equity Crowdfunding)

25 Pasal 24 jo. 25 POJK No. 37 /POJK.04/2018 tentang Layanan Urun Dana Melalui Penawaran Saham Berbasis Teknologi Informasi (Equity Crowdfunding)
} 
isi perjanjian tentang Layanan Urun Dana. Perjanjian tersebut dapat memuat ketentuan mengenai pemberian kuasa kepada penyelenggara untuk mewakili pemodal sebagai pemegang saham penerbit termasuk dalam rapat umum pemegang saham penerbit dan penandatanganan akta serta dokumen terkait lainnya. ${ }^{26}$

Berdasarkan perjanjian antara penyelenggara dan pemodal, pemodal membeli saham milik penerbit yang ditawarkan melalui penyelenggara dengan menyetorkan sejumlah dana pada escrow account. ${ }^{27}$ Adapun yang dimaksud dengan Escrow Account adalah rekening yang dibuka secara khusus untuk tujuan tertentu guna menampung dana yang dipercayakan kepada Bank Indonesia berdasarkan persyaratan tertentu sesuai dengan perjanjian tertulis. ${ }^{28}$ Tujuan penggunaan escrow account dalam hal ini yaitu melarang penyelenggara melakukan penghimpunan dana masyarakat melalui rekening penyelenggara. Guna mendukung penggunaan virtual account dan escrow account tersebut maka penyelenggara harus bekerjasama dengan pihak bank.

Penyelenggara wajib mendistribusikan saham kepada Pemodal paling lambat 10 hari kerja setelah menerima saham dari penerbit. Pendistribusian tersebut dapat dilakukan secara elektronik melalui penitipan kolektif pada kustodian atau pendistribusian secara fisik melalui pengiriman sertifikat saham..$^{29}$ Pada distribusi saham secara elektronik melalui penitipan kolektif pada kustodian, penerbit wajib terlebih dahulu melakukan perjanjian dengan Lembaga Penyimpanan dan Penyelesaian dan pemodal telah memiliki rekening Efek pada kustodian. Adapun yang dimaksud dengan "kustodian" adalah pihak yang memberikan jasa penitipan Efek dan harta lain yang berkaitan dengan Efek serta jasa lain, termasuk menerima dividen, bunga, dan hak - hak lain, menyelesaikan transaksi Efek, dan mewakili pemegang rekening yang menjadi nasabahnya.

\footnotetext{
26 Pasal 45 POJK No. 37 /POJK.04/2018 tentang Layanan Urun Dana Melalui Penawaran Saham Berbasis Teknologi Informasi (Equity Crowdfunding)

27 Pasal 29 POJK No. 37 /POJK.04/2018 tentang Layanan Urun Dana Melalui Penawaran Saham Berbasis Teknologi Informasi (Equity Crowdfunding)

28 Penjelasan atas Peraturan Bank Indonesia No. 3/11/PBI/2001 tentang Perubahan Atas Perubahan Atas Peraturan Bank Indonesia No. 2/24/PBI/2000 tentang Hubungan Rekening Giro Antara Bank Indonesia dengan Pihak Ekstern

29 Pasal 31 ayat (2) dan (3) POJK No. 37 /POJK.04/2018 tentang Layanan Urun Dana Melalui Penawaran Saham Berbasis Teknologi Informasi (Equity Crowdfunding)
} 
Berdasarkan hal di atas, tampak perbedaan antara pembelian saham perseroan melalui equity crowdfunding dengan pembelian saham perseroan dalam skema pasar modal baik pada pasar perdana maupun pasar sekunder. Saham pada equity crowdfunding tidak wajib bersifat scriptless sedangkan saham yang diperdagangkan dalam pasar perdana maupun pasar sekunder dalam skema perdagangan saham di pasar modal bersifat scriptless. Hal ini membawa konsekuensi tidak wajibnya pelibatan lembaga penyimpanan dan penyelesaian serta kustodian.

\section{Hubungan Hukum antara Penerbit dan Pemodal}

Penerbit dan pemodal dalam equity crowdfunding tidak bertemu secara langsung melainkan melalui perantara penyelenggara equity crowdfunding. Meskipun demikian, penerbit dan pemodal memiliki hubungan hukum yang lahir dari perjanjian jual beli saham. Hubungan hukum jual beli saham ini tersirat dari berbagai pasal dalam POJK No. 37/POJK.04/2018 tentang Layanan Urun Dana Melalui Penawaran Saham Berbasis Teknologi Informasi (Equity Crowdfunding) dimana terdapat kata-kata penjualan, pembelian, serta penjual dan pembeli. Maksud dari pengaturan yang terdapat dalam POJK tersebut jelas mengarah kepada perjanjian jual beli saham antara penerbit dan pemodal melalui penyelenggara.

Dasar hukum jual beli adalah Pasal 1457 sampai dengan 1540 Kitab UndangUndang Hukum Perdata (KUHPerdata). Penerbit dalam hal ini bertindak selaku perseroan terbatas yang menjual saham yang dimilikinya (saham tersebut berasal dari saham dalam portepel) kepada pemodal. Berdasarkan konsep perjanjian jual beli tersebut, penerbit memiliki kewajiban untuk menyerahkan saham kepada pemodal selaku pembeli dan pemodal memiliki kewajiban untuk memberikan sejumlah uang pembayaran atas saham yang dibeli.

Perjanjian jual beli sesuai KUHPerdata, harus dilakukan dengan barang tertentu atau barang yang baru akan ada dikemudian hari dengan ketentuan barang tersebut dapat ditentukan baik jenis maupun jumlahnya dikemudian hari. ${ }^{30}$ Perusahaan penerbit saham dalam konsep equity crowdfunding, seharusnya memiliki saham dalam portepel (portofolio shares) atau setidak-tidaknya memiliki rencana penambahan saham baru. Perusahaan penerbit saham menyetujui penerbitan saham

${ }^{30}$ Lihat Pasal 1334 KUHPerdata 
baru (issuing new shares) melalui Rapat Umum Pemegang Saham (RUPS) dengan terlebih dahulu melakukan penawaran umum saham baru ke pemegang saham yang sudah ada (the existing shareholders) sebelum perusahaan penerbit bekerja sama dengan perusahaan penyelenggara dalam rangka penawaran saham. Jika pada saat penerbit menandatangani kerjasama penyelenggaraan equity crowdfunding dengan penyelenggara tidak memiliki saham dalam portepel dan tidak memiliki rencana penambahan saham baru serta tidak memiliki persetujuan RUPS guna penambahan saham baru, maka iktikad baik penerbit dalam hal ini patut untuk ditinjau. Mengingat keberadaan saham dalam perjanjian jual beli saham merupakan unsur objektif dari sahnya perjanjian jual beli saham antara para pihak.

Saham merupakan sejumlah uang yang diinvestasikan oleh investor dalam suatu perseroan dan atas investasi pemegang saham (aandelhouder/shareholder) mendapat keuntungan dari perseroan dalam bentuk deviden. ${ }^{31}$ Saham dalam hukum perdata dianggap benda bergerak yang tidak berwujud. Pasal 60 ayat (1) Undang-Undang No. 40 Tahun 2007 tentang Perseroan Terbatas menyatakan bahwa saham merupakan benda bergerak. Selanjutnya Pasal 56 ayat (1) UndangUndang No. 40 Tahun 2007 tentang Perseroan Terbatas menyatakan bahwa pemindahan hak atas saham dilakukan dengan akta pemindahan hak. UndangUndang No. 40 Tahun 2007 tentang Perseroan Terbatas hanya mengakui saham atas nama saja. Akta pemindahan hak tersebut dapat dilakukan dengan akta notaris (akta otentik) maupun dengan akta di bawah tangan (private deed). ${ }^{32}$

Penerbit wajib mencatatkan kepemilikan saham Pemodal dalam daftar pemegang saham. ${ }^{33}$ Pasal 50 ayat (1) Undang-Undang No. 40 Tahun 2007 tentang Perseroan Terbatas mewajibkan direksi perseroan untuk mengadakan dan menyimpan daftar pemegang saham, yang memuat sekurang-kurangnya:

a. nama dan alamat pemegang saham;

b. jumlah, nomor, tanggal perolehan saham yang dimiliki pemegang saham, klasifikasinya dalam hal dikeluarkan lebih dari satu klasifikasi saham;

c. jumlah yang disetor atas setiap saham;

d. nama dan alamat dari orang-perorangan atau badan hukum yang

${ }^{31}$ M. Yahya Harahap, Hukum Perseroan Terbatas, Sinar Grafika, Jakarta, 2011, hlm. 257.

32Ridwan Khairandy, Perjanjian Jual Beli, FH UII Press, Yogyakarta, 2016, hlm. 129.

${ }_{33}$ Pasal 41 POJK No. 37 /POJK.04/2018 tentang Layanan Urun Dana Melalui Penawaran Saham Berbasis Teknologi Informasi (Equity Crowdfunding) 
mempunyai hak gadai saham atau sebagai penerima jaminan fidusia saham dan tanggal perolehan hak gadai atau tanggal pendaftaran jaminan fidusia tersebut; dan

e. keterangan penyetoran saham dalam bentuk lain.

Selain daftar pemegang saham tersebut, direksi perseroan wajib mengadakan dan menyimpan daftar khusus yang memuat keterangan mengenai saham anggota direksi dan dewan komisaris beserta keluarganya dalam perseroan dan/atau perseroan lain serta tanggal saham diperoleh. Daftar pemegang saham dan daftar khusus tersebut dicatat juga setiap perubahan kepemilikan saham. Daftar pemegang saham dan daftar khusus tersebut wajib disediakan ditempat kedudukan perseroan agar dapat dilihat oleh para pemegang saham. ${ }^{34}$

Penerbit memiliki kewajiban untuk melaksanakan disclosure information. Penerbit wajib menyampaikan informasi mengenai perusahaan yang dikelola termasuk perubahan material yang dapat memengaruhi keputusan investasi Pemodal. Keterbukaan informasi tersebut juga harus memuat mengenai risiko, paling sedikit meliputi risiko usaha, investasi, likuiditas, kelangkaan pembagian dividen, dilusi kepemilikan saham, dan kegagalan Sistem Elektronik. Risiko yang berkaitan dengan kegagalan sistem elektronik dapat berupa a) platform mengalami eror pada saat pengguna menggunakannya (tidak bisa log in) disebabkan kurangnya manajemen software perusahaan b) apabila manajemen software perusahaan tidak terkelola dengan baik, dapat mengakibatkan transaksi tidak terperbaharui dengan baik, c) hilangnya database konsumen setelah informasi didaftarkan pada platform perusahaan, dan d) ada bank-bank tertentu yang tidak bisa diakses dikarenakan sistem keamanan bank yang terus diperbaharui dan perusahaan fintech harus melakukan penyesuaian. ${ }^{35}$ Informasi mengenai risiko-risiko tersebut harus diunggah dalam situs web penyelenggara, dan baik penerbit maupun penyelenggara secara sendiri-sendiri maupun bersama-sama bertanggung jawab sepenuhnya atas kebenaran semua informasi yang tercantum dalam layanan urun dana (equity crowdfunding).

\footnotetext{
${ }^{34}$ Ridwan Khairandy, Hukum Perseroan Terbatas Doktrin, Peraturan Perundang-Undangan, dan Yurisprudensi, Kreasi Total Media, Yogyakarta, 2009, hlm. 95 - 96.

${ }^{35}$ Basrowi, "Analisis Aspek dan Upaya Perlindungan Konsumen Fintech Syariah”, Lex Librum Jurnal Ilmu Hukum, Vol. 5 No. 2. 2019.
} 
Perlindungan Hukum bagi Para Pihak dalam Layanan Urun Dana Melalui Penawaran Saham Berbasis Teknologi Informasi (Equity Crowdfunding) di Indonesia

Meskipun Otoritas Jasa Keuangan telah memberikan rambu-rambu isi perjanjian antara penerbit dan penyelenggara, namun belum terdapat standar baku perjanjian antara penerbit dan penyelenggara equity crowdfunding di Indonesia, bahkan bentuk perjanjiannya pun dapat berupa akta otentik maupun akta di bawah tangan. Oleh karenanya, perjanjian antara penerbit dan penyelenggara equity crowdfunding satu dengan lainnya dapat memiliki isi perjanjian yang berbeda asalkan memuat ketentuan minimal yang diatur dalam Pasal 44 POJK No. 37 /POJK.04/2018 tentang Layanan Urun Dana Melalui Penawaran Saham Berbasis Teknologi Informasi (Equity Crowdfunding). Isi dari perjanjian antara penerbit dan penyelenggara tentu akan berdampak pada pemodal, pihak yang tidak terlibat sebagai pihak dalam perjanjian antara penerbit dan penyelenggara namun menjadi pihak yang akan menerima dampak dari perjanjian tersebut.

Disisi lain, bentuk perjanjian baku antara penyelenggara dan pemodal memberikan konsekuensi hukum bahwa pemodal tidak memiliki kesempatan untuk melakukan negosiasi atas ketentuan dalam perjanjian melainkan hanya memiliki opsi untuk menerima atau menolak isi perjanjian (take it or leave it). Jika pemodal memutuskan untuk menerima ketentuan dalam perjanjian baku tersebut, pemodal cukup melakukan klik setuju pada tombol tertentu yang telah disediakan oleh penyelenggara pada sistem yang dimiliki. Bentuk bakunya perjanjian antara pemodal dan penyelenggara tersebut dapat memberikan peluang besar kepada penyelenggara untuk mencantumkan ketentuan bahwa penyelenggara memiliki hak atas inisiatif penyelenggara sendiri, untuk menambah atau mengganti ketentuan apapun dalam perjanjian atau mengubah, menunda, maupun memberhentikan layanan sewaktu-waktu. ${ }^{36}$

Selain itu, pemodal dalam equity crowdfunding perlu memahami hak-hak yang dimiliki. Sebagai pemegang saham perseroan terbatas, pemegang saham memiliki hak untuk hadir dan bersuara di rapat umum pemegang saham serta

${ }^{36}$ Lin Lin, "Managing the Risks of Equity Crowdfunding: Lessons from China”, Journal of Corporate Law Studies - Centre For Banking and Finance Law. National University of Singapore, 2017, hlm. 14 
hak mendapatkan dividen dan sisa kekayaan hasil likuidasi perseroan. ${ }^{37}$ Namun hak pemegang saham dalam equity crowdfunding memiliki perbedaan dengan hak pemegang saham perseroan yang tercatat di bursa efek. Hal ini disebabkan perdagangan dalam equity crowdfunding sampai saat ini tidak termasuk dalam perdagangan di bursa efek mengingat equity crowdfunding memiliki pasar perdana dan pasar sekunder yang terpisah dari bursa. Pemodal sebagai pemegang saham dalam equity crowdfunding tidak dapat menjual saham yang dimiliki sewaktuwaktu seperti halnya pemegang saham perseroan yang listed di bursa efek.

Berdasarkan Pasal 32 POJK tentang equity crowdfunding, penyelenggara dapat menyediakan sistem bagi Pemodal untuk memperdagangkan saham penerbit yang telah dijual melalui Layanan Urun Dana yang diselenggarakannya. Ketentuan tersebut menggunakan kata "dapat" yang berarti penyelenggara dapat menyediakan pasar sekunder ataupun tidak menyediakan pasar sekunder. Tentu berdasarkan hal ini, risiko likuiditas atas saham yang dimiliki merupakan hal yang harus dipahami oleh pemodal. Pemodal dalam equity crowdfunding sangat kecil sekali memiliki peluang untuk mendapatkan capital gain seperti halnya pemegang saham perseroan yang listed di bursa. Perlindungan atas harga saham pada perusahaan penerbit juga belum mendapatkan pengaturan sebagaimana pengaturan dalam perdagangan di bursa efek.

Sebagai contoh salah satu perusahaan penerbit yang telah terdaftar di OJK yaitu Santara (santara.co.id) yang menyediakan pasar sekunder namun dengan pembatasan tertentu yakni pasar sekunder yang dibuka dua kali dalam setahun. Adapun harga saham yang ditawarkan di pasar sekunder adalah sama dengan harga beli awal. Dengan demikian, tidak dikenal istilah capitalgain di dalam pasar sekunder Santara dan pemodal hanya menerima nilai bagi hasil dari investasi yang ditanamkannya. Meskipun demikian Santara tetap berupaya untuk meminimalisir risiko likuiditas tersebut, yakni dengan memberikan persyaratan kepada penerbit untuk melakukan buyback sejumlah persentase tertentu atas saham yang beredar di secondary market. ${ }^{38}$

\footnotetext{
37 Pasal 52 Undang-Undang No. 40 Tahun 2007 tentang Perseroan Terbatas

${ }^{38}$ https://investasi.kontan.co.id/news/jadi-equity-crowdfunding-berizin-pertama-begini-gambaraninvestasi-di-santara?page $=2$ diakses pada tanggal 30 September 2019 pukul $13.00 \mathrm{WIB}$
} 


\section{Penutup}

Berdasarkan pembahasan di atas, dapat disimpulkan bahwa para pihak dalam penyelenggaraan equity crowdfunding yaitu penerbit saham, penyelenggara, dan pemodal. Tiga pihak dalam equity crowdfunding tersebut memiliki triangular relationship yang lahir berdasarkan perjanjian maupun peraturan perundangundangan dimana penerbit memberikan kuasa kepada penyelenggara guna menjualkan saham kepada pemodal. Perlu dipahami bahwa meskipun equity crowdfunding merupakan alternatif pembiayaan bagi penerbit dan merupakan alternatif investasi bagi pemodal dengan skema jual beli saham, namun hak dan kewajiban penerbit maupun pemodal dalam equity crowdfunding berbeda dengan hak dan kewajiban antara Emiten dan pemegang saham dalam konsep perdagangan di bursa efek. Meskipun OJK telah menerbitkan peraturan terkait equity crowdfunding, pengaturan yang ada saat ini belum sepenuhnya memberikan jaminan perlindungan hukum khususnya bagi pemodal. Oleh karena itu pengaturan lebih lanjut atas jaminan perlindungan hukum bagi para pihak khususnya pemodal sangat diperlukan.

\section{Daftar Pustaka}

\section{Buku}

Darmadji, Tjiptono dan Hendy M. Fakhruddin, Pasar Modal Indonesia Edisi 3, Salemba Empat, Jakarta, 2011.

Harahap, M. Yahya, Hukum Perseroan Terbatas, Sinar Grafika, Jakarta, 2011.

Khairandy, Ridwan, Perjanjian Jual Beli, FH UII Press, Yogyakarta, 2016.

Hukum Perseroan Terbatas Doktrin, Peraturan Perundang-Undangan, dan Yurisprudensi, Kreasi Total Media, Yogyakarta, 2009.

Paramono, Nindyo, Hukum PT Go Public dan Pasar Modal, Andi, Yogyakarta, 2013.

\section{Jurnal}

Aprilia, Lady dan Sigit S. Wibowo, "The Impact of Social Capital On Crowdfunding Performance" The South East Asean Journal of Management, Vol. 11 No. 1. 2017.

Basrowi. "Analisis Aspek dan Upaya Perlindungan Konsumen Fintech Syariah". Lex Librum Jurnal Ilmu Hukum, Vol. 5 No. 2. 2019. 
Josua, Gustaf at.al. “Tinjauan Yuridis Terhadap Penerapan Prinsip Keterbukaan Dan Mitigasi Resiko Pada Equity Crowdfunding Di Indonesia," Jurnal Hukum Fakultas Hukum Universitas Brawijaya, 2019.

Lin Lin. "Managing the Risks of Equity Crowdfunding: Lessons from China" Journal of Corporate Law Studies - Centre For Banking and Finance Law. National University of Singapore. Singapore, 2017.

Vina, Lynda Y. de la dan Stephanie Lee Black. “US Equity Crowdfunding: A Review of Current Legislation and A Conceptual Model of The Implications For Equity Funding". The Journal of Entrepreneurship, Sage Publications. 2017.

\section{Peraturan Perundang-Undangan}

Kitab Undang-Undang Hukum Perdata

Undang-Undang No. 8 Tahun 1995 tentang Pasar Modal

Undang-Undang No. 40 Tahun 2007 tentang Perseroan Terbatas

Peraturan Presiden No. 44 Tahun 2016 tentang Daftar Negatif Investasi

Peraturan Presiden Nomor 82 Tahun 2016 tentang Strategi Nasional Keuangan Inklusif

POJK No. 37 /POJK.04/2018 tentang Layanan Urun Dana Melalui Penawaran Saham Berbasis Teknologi Informasi (Equity Crowdfunding)

POJK No. 77/POJK.01/2016 tentang Layanan Pinjam Meminjam Berbasis Teknologi Informasi

Peraturan Bank Indonesia No. 3/11/PBI/2001 tentang Perubahan Atas Perubahan Atas Peraturan Bank Indonesia No. 2/24/PBI/2000 tentang Hubungan Rekening Giro Antara Bank Indonesia dengan Pihak Ekstern

\section{Internet}

https://dictionary.cambridge.org/dictionary/english/crowdfunding diakses pada tanggal 6 September 2019 pukul 15.43 WIB.

https: / / market.bisnis.com/read/20190923/7/1151262/bei-9-platform-sudahmengajukan-diri-jadi-equity-crowd-funding diakses pada tanggal 25 September 2019 pukul 16.17 WIB

https: / teknologi.bisnis.com/read/20190808/266/1134219/investor-asing-distartup-indonesia-masih-tuai-kontroversi diakses pada tanggal 8 September 2019 pukul 15.49 WI

https:/ /investasi.kontan.co.id/news/jadi-equity-crowdfunding-berizin-pertamabegini-gambaran-investasi-di-santara?page $=2$ diakses pada tanggal 30 September 2019 pukul 13.00 WIB 